\title{
EFEKTIVITAS SEKOLAH: KEPEMIMPINAN VISIONER KEPALA SEKOLAH DAN IKLIM SEKOLAH
}

\author{
Rinel $^{1}$ \\ ${ }^{1}$ Sekolah Menengah Atas Haurgeulis, Indramayu, rinel_sma1@gmail.com
}

\begin{abstract}
ABSTRAK
Telah dilakukan penelitian untuk mengetahui pengaruh kepemimpinan visioner kepala sekolah dan iklim sekolah terhadap sekolah efektif. Penelitian dilakukan di Sekolah Menengah Atas (SMA) Gugus Kendali Tugas (Guligas IV) Kabupaten Indramayu. Teori yang melandasi penelitian ini adalah teori kepemimpinan visioner, teori iklim sekolah dan teori sekolah efektif. Penelitian ini menggunakan pendekatan kuantitatif dengan metode survey dan angket. Responden berjumlah 72 orang dari SMA negeri dan swasta yang ada di Guligas IV Kabupaten Indramayu. Instrumen penelitian berbentuk kuesioner divalidasi dengan menggunakan analisis butir Korelasi Pearson dan reabilitas total butir menggunakan Alpha Cronbach. Analisis data menggunakan regresi tunggal dan regresi ganda dengan bantuan SPSS versi 24 for Windows. Hasil penelitian ini menyimpulkan bahwa: 1.Terdapat pengaruh yang positif dan signifikan pada kepemimpinan visioner kepala sekolah terhadap terwujudnya efektivitas sekolah di SMA Se-Guligas IV Kabupaten Indramayu dengan besaran pengaruh 33,9\%; 2.Terdapat pengaruh yang positif dan signifikan pada iklim sekolah terhadap terwujudnya efektivitas sekolah di SMA SeGuligas IV Kabupaten Indramayu dengan besaran pengaruh 43,1\%; 3.Terdapat pengaruh . yang positif dan signifikan pada kepemimpinan visioner kepala sekolah dan iklim sekolah secara bersama-sama terhadap terwujudnya efektivitas sekolah di SMA Se-Guligas IV Kabupaten Indramayu dengan besaran $58,2 \%$.
\end{abstract}

\section{Kata kunci: Efektivitas Sekolah, Kepemimpinan Visioner, Iklim Sekolah.}

\section{PENDAHULUAN}

Salah satu topik yang banyak disoroti dalam penyelenggaraan pendidikan adalah masalah peningkatan mutu pendidikan, baik di tingkat nasional maupun di institusi penyelenggara pendidikan itu sendiri. Pemerintah berupaya meningkatkan mutu pendidikan melalui UU No.20 tahun 2003 pasal 35 dan PP N0.19 tahun 2005 tentang Standar Nasional Pendidikan. Dengan adanya standar ini setiap institusi pendidikan tidak akan mengalami penafsiran yang berbeda terhadap mutu pendidikan, artinya bahwa mutu pendidikan dinilai baik bila telah memenuhi bahkan melampaui Standar Nasional Pendidikan tersebut.

Data yang dapat ditinjau secara statistik terhadap mutu penyelenggaraan pendidikan di Indonesia adalah hasil Ujian Nasional (UN), dimana hasil UN ini merupakan salah satu output prestasi akademik siswa di sekolah. Setiap tahun kualitas soal dan penyelenggaraan UN selalu ditingkatkan agar dapat mengukur mutu penyelenggaraan pendidikan dengan baik. Pada situs resmi pemerintah (kemndikbud, 2015) dan terdapat 
laporan hasil ujian nasional untuk tahun 2014-2015 dan 2015-2016. Dari rekapan data hasil ujian nasional di SMA Kabupaten/Kota se Jawa Barat dan SMA Negeri dan Swasta se-Kabupaten Indramayu selama dua tahun berturut-turutmenunjukkan bahwa posisi perolehan nilai UN SMA untuk Kabupaten Indramayu menempati kedudukan kedua terendah dari 27 kabupaten/kota yang ada di Jawa Barat. Kondisi ini menunjukkan bahwa penyelenggaraan pendidikan di Kabupaten Indramayu butuh perhatian khusus. Dan kalau dikelompokkan berdasarkan gugus kendali tugas (Guligas) yang terdiri dari lima guligas, ternyata dari kelima guligas tersebut yang menunjukkan perolehan nilai UN paling rendah adalah guligas empat. Maka pada kesempatan ini penulis akan memfokuskan penelitian pada sekolah-sekolah menengah atas yang ada di Guligas IV Kabupaten Indramayu.

Adanya permasalahan pada hasil ujian nasional ini tidak terlepas dari bagaimana proses penyelenggaraan pendidikan yang terjadi di sekolah. Berdasarkan pandangan tradisional menurut Sergiovanni (1987:162) bahwa organisasi dikategorikan efektif apabila mencapai tujuan yang telah ditetapkan. Tidak tercapainya nilai UN sebagai salah satu Standar Nasional Pendidikan ini mengindikasikan bahwa karakteristik proses dan kondisi sekolah belum cukup efektif dalam mencapai tujuan sekolah. Rohiat (2010:57) menjelaskan bahwa jika sekolah ingin sukses dalam menerapkan Manajemen Berbasis Sekolah (MBS) maka sejumlah karakteristik MBS perlu dimiliki. Karakteristik MBS tidak dapat dipisahkan dengan efektivitas sekolah, karena jika diibaratkan MBS merupakan wadahnya maka efektivitas sekolah merupakan isinya.

Walaupun masih ditemukan berbagai persoalan dalam pelaksanaannya, namun terdapat relevansi antara UN di Indonesia dengan peningkatan mutu pendidikan sekolah, guru, orang tua, dan peserta didik. Salah satu masalah yang dapat diangkat dari persoalan ini adalah kondisi sekolah yang masih kurang efektif. Ketidakefektifan sekolah di SMA Guligas IV Kabupaten Indramayu ini dapat disebabkan oleh faktor input sekolah yang belum maksimal, baik sumber daya manusia seperti rekruitment siswa serta sumber daya fisik yang belum memadai. Faktor lain adalah proses yang terjadi disekolah itu sendiri berkaitan dengan manajemen sekolah, manajemen sekolah yang belum berjalan dengan baik sehingga mempengaruhi lulusan yang dihasilkan. Yang akan ditelaah lebih lanjut oleh peneliti adalah faktor manajemen yang dapat mempengaruhi efektivitas sekolah itu sendiri, yaitu kepemimpinan kepala sekolah sebagai orang yang punya visi dan melakukan tindakan terhadap pencapaian visi tersebut. Karena sekolah yang efektif adalah sekolah yang mampu mencapai tujuannya dengan maksimal. Faktor lain yang dapat mempengaruhi pula yaitu iklim sekolah dimana iklim yang positif akan mendorong 
seluruh warga sekolah untuk bersemangat dalam menjalankan tugas dan tanggung jawabnya masing-masing dalam mencapai tujuan sekolah.

\section{METODE PENELITIAN}

Penelitian pendidikan ini menggunakan metode penelitian kuantitatif. Populasi sasaran dalam penelitian ini adalah seluruh guru SMA Negeri dan Swasta se- Gugus Kendali Tugas (guligas) IV Kabupaten Indramayu, tahun ajaran 2016-2017. Ukuran sampel dari populasi dalam penelitian ini dihitung dengan rumus Taro Yamane atau Slovin (Ridwan, 2007:65), sehingga sampel yang akan diteliti adalah sebanyak 72 orang.Adapun teknik pengumpulan data yang dilakukan dalam penelitian ini adalah dokumentasi dan kuesioner atau angket. Pada penelitian ini uji validitas dilakukan dengan menggunakan fasilitas olah data pada software SPSS versi 24 tentang uji korelasi Pearson dan reliabilitasnya juga menggunakan fasilitas olah data software SPSS versi 24 tentang uji reliabilitas Alpha Cronbach.

Dalam penelitian ini uji normalitas data dilakukan menggunakan model uji Kolmogorov-Smirnov dengan program SPSS versi 24 yang bertujuan untuk mengetahui asumsi kenormalan tercapai atau tidak, begitu pula uji reliabilitas menggunakan program SPSS versi 24. Sedangkan pengujian hipotesis ini dengan analisis korelasi product moment dilakukan dengan program SPSS.

\section{HASIL DAN PEMBAHASAN}

Dari hasil analisis data angket mengenai kepemimpinan kepala sekolah yang disebarkan kepada 72 responden terdiri dari 30 item pernyataan yang telah diuji validitas dan reabilitasnya. Jumlah skor kepemimpinan visioner adalah 9148, dengan rata-rata 127,06, standar deviasi 17,897 serta varians 320,307. Sedangkan skor tertinggi dalam angket variabel ini yaitu 150 dan skor terendah 68. Skor ideal variabel kepemimpinan visioner adalah 150. Persentase variabel kepemimpinan adalah 84,71\%. Sehingga angka persentase kepemimpinan visioner di Guligas IV SMA di Kabupaten Indramayu berada dalam kategori sangat baik.

Angka persentase perdimensi pada variabel Kepemimpinan Visioner menunjukkan kriteria sangat baik pada semua dimensi, yaitu dimensi penentu arah, agen perubahan, juru bicara, pelatih dan motivator. Angket mengenai iklim sekolah yang disebarkan kepada 72 responden terdiri dari 25 item pernyataan yang telah diuji validitas dan reabilitasnya. Berdasarkan tabel 4.1 jumlah skor iklim sekolah adalah 7686, dengan rata-rata 106,75, 
standar deviasi 7,961, serta varians 63,373. Sedangkan skor tertinggi dalam angket variabel ini yaitu 120 dan skor terendah 63. Skor ideal variabel iklim sekolah adalah 125. Persentase variabel iklim sekolah adalah 85,40 \% Sehingga angka persentase iklim sekolah di Guligas IV SMA di Kabupaten Indramayu berada dalam kategori sangat baik.Dari lima dimensi terhadap variabel iklim sekolah diperoleh empat dimensi berada pada kriteria sangat baik yaitu standar disiplin, penghargaan, harapan dan suasana harmonis, sedangkan untuk dimensi lingkungan fisik berada pada kriteria baik. Angket mengenai efektivitas sekolah yang disebarkan kepada 72 responden terdiri dari 29 item pernyataan yang telah diuji validitas dan reabilitasnya. Berdasarkan tabel 4.1 jumlah skor efektivitas sekolah adalah 8997, dengan rata-rata 124,96, standar deviasi 11,898, serta varians 141,562. Sedangkan skor tertinggi dalam angket variabel ini yaitu 145 dan skor terendah 86. Skor ideal variabel iklim sekolah adalah 145. Data statistik deskriptif variabel Efektivitas sekolah (Y) diperoleh angka prosentase menjadi86,18\%. Skor tersebut juga berada pada kriteria tinggi, dan dapat disimpulkan bahwa Efektivitas sekolah di Guligas IV Kabupaten Indramayu tergolong sangat baik. Dari ketiga dimensi pada variabel efektivitas sekolah angka persentasenya berada pada kriteria sangat baik.

Hasil uji Normalitas yang dilakukan dengan teknik Kolmogorov-Smirnov, nilai Asymp. Sig. (2-tailed) untuk variabel kepemimpinan visioner adalah 0,064, variabel iklim sekolah adalah 0,093 dan variabel efektivitas sekolah adalah 0,200. Semua nilai Asym.sig. (2-tailed) ketiga variabel tersebut > 0,05, artinya signifikan. Kesimpulannya hasil uji normalitas dari ketiga variabel penelitian baik Kepemimpinan visioner, Iklim sekolah dan Efektivitas sekolah berdistribusi normal, sehingga memenuhi syarat untuk melakukan uji regresi.

Hasil uji linearitas variabel kepemimpinan visioner $\left(\mathrm{X}_{1}\right)$ terhadap variabel Efektivitas sekolah (Y) dimana didapatkan angka signifikansi linearitas 0,00 dan sig. deviation from Linearity sebesar 0,159. Angka sig. Linearity <0,05 dan angka bahwa data variabel kepemimpinan visioner $\left(\mathrm{X}_{1}\right)$ linear dengan data variabel Efektivitas sekolah. Sedangkan hasil uji linearitas variabel Iklim Sekolah $\left(\mathrm{X}_{2}\right)$ terhadap variabel efektivitas sekolah (Y) ditampilkan pada tabel 4.17. Dari hasil analisis didapatkan angka signifikansi linearity 0,00 dan sig. deviation from Linearity sebesar 0,362. Angka sig. Linearity $<0,05$ dan angka sig.deviation from Linearity > 0,05 menunjukkan bahwa data variabel Iklim sekolah (X1) linear dengan data variabel Efektivitas sekolah.

Hasil perhitungan analisis korelasi pada data kepemimpinan visioner terhadap efektivitas sekolah diperoleh besarnya korelasi $\left(r_{x 1 y}\right)$ antara variabel kepemimpinan 
visioner kepala sekolah $\left(\mathrm{X}_{1}\right)$ terhadap efektivitas sekolah (Y) dengan Pearson Correlation adalah 0,582. Hal ini menunjukkan adanya hubungan yang positif antara kepemimpinan visioner kepala sekolah dengan efektivitas sekolah. Pengujian lanjutan tentang kebermaknaan hubungan antara variabel $\mathrm{X}_{1}$ terhadap $\mathrm{Y}$ dilakukan melalui uji $\mathrm{t}$ diperoleh $\mathrm{t}$ hitung sebesar 5,988, sedangkan $t$ tabel adalah 2,291. Karena $t_{\text {hitung }}(5,988)>t_{\text {tabel }}(2,291)$ dan sig. $(0,000)<\mathrm{P}(0,05)$ maka $\mathrm{H}_{0}$ ditolak dan $\mathrm{H}_{1}$ diterima. Dengan demikian hipotesis yang menyatakan bahwa terdapat pengaruh positif dan signifikan antara kepemimpinan visioner kepala sekolah dan efektivitas sekolah di SMA Guligas IV Kabupaten Indramayu diterima. Besaran sumbangan pengaruh variabel $\mathrm{X}_{1}$ terhadap $\mathrm{Y}$ dapat dihitung dengan koefisien determinasidiperoleh data bahwa $\mathrm{R}$ square sebesar 0,339. Ini berarti bahwa koefisien determinasi $=\mathrm{r}^{2} \times 100 \%=(0,582)^{2} \times 100 \%=33,9 \%$ artinya variabel Efektivitas sekolah (Y) dipengaruhi oleh variabel kepemimpinan vsioner $\left(\mathrm{X}_{1}\right)$. Sebesar 33,9\%, dan sisanya sebesar $66,1 \%$ dipengaruhi oleh variabel iklim sekolah serta variabel lain yang tidak diteliti dalam penelitian ini

Hasil perhitungan analisis regresi pada iklim sekolah terhadap efektivitas sekolah diperoleh databesarnya hubungan $\left(\mathrm{r}_{\mathrm{x} 1 \mathrm{y}}\right)$ antara variabel iklim sekolah $\left(\mathrm{X}_{2}\right)$ dengan Pearson Correlation terhadap efektivitas sekolah (Y) adalah 0,656. Hal ini menunjukkan bahwa terdapat hubungan yang positif antara iklim sekolah dan efektivitas sekolah. Berikutnya diperoleh persamaan regresi dari hasil perhitungan diperoleh $\widehat{Y}=20,231+0,981 X X 2$. Konstanta sebesar 20,231 menyatakan bahwa jika tidak ada kenaikan nilai dari variabel iklim sekolah $\left(\mathrm{X}_{2}\right)$, maka efektivitas sekolah (Y) adalah 20,231. Koefisien regresi sebesar 0,981 menyatakan bahwa setiap perubahan satu unit atau nilai iklim sekolah memberikan kenaikan skor sebesar 0,981 unit. Selanjutnya pengujian signifikansi dilakukan dengan membandingkan antara nilai probabilitas 0,05 dengan nilai probabilitas diperoleh nilai sig $0,000<0,05$, maka terdapat pengaruh iklim sekolah $\left(\mathrm{X}_{2}\right)$ yang signifikan terhadap efektivitas sekolah (Y). Pengujian lanjutan tentang kebermaknaan hubungan antara variabel $\mathrm{X}_{2}$ terhadap $\mathrm{Y}$ dilakukan melalui uji t. Dari perhitudingan peroleh $\mathrm{t}_{\text {hitung }}$ sebesar 7,280 , sedangkan $t$ tabel adalah 2,291. Karena $t_{\text {hitung }}(7,280)>t_{\text {tabel }}(2,291)$ dan sig. $(0,000)$ $<\mathrm{P}(0,05)$ maka $\mathrm{H}_{0}$ ditolak dan $\mathrm{H}_{1}$ diterima. Dengan demikian hipotesis yang menyatakan bahwa ada terdapat pengaruh positif dan signifikan antara iklim sekolah dan efektivitas sekolah di SMA Guligas IV Kabupaten Indramayu diterima. Besaran sumbangan pengaruh variabel $\mathrm{X}_{2}$ terhadap $\mathrm{Y}$ dapat dihitung dengan koefisien determinasidiperoleh data bahwa $\mathrm{R}$ square sebesar 0,431. Ini berarti bahwa koefisien determinasi $=r^{2} \times 100 \%=(0,656)^{2} \mathrm{x}$ $100 \%=43,1 \%$ artinya variabel Efektivitas sekolah $(\mathrm{Y})$ dipengaruhi oleh variabel iklim 
sekolah $\left(\mathrm{X}_{2}\right)$ sebesar 43,1\%, dan sisanya sebesar 56,9\% dipengaruhi oleh variabel kepemimpinan kepala sekolah $\left(\mathrm{X}_{1}\right)$ serta variabel lain yang tidak diteliti dalam penelitian ini.

Untuk mengetahui persamaan regresi ganda antara variabel $\mathrm{X}_{1}$ dan $\mathrm{X}_{2}$ secara simultan terhadap $\mathrm{Y}$, dapat dilihat pada tabel 4.24 bahwa $\mathrm{a}=7,027$, koefisien $\mathrm{X}_{1}=0,273$ dan koefisien $\mathrm{X}_{2}=0,780$. Dengan demikian persamaan regresi gandanya adalah: $\hat{Y}=$ $7,027+0,273 \mathrm{X}_{1}+0,780 \mathrm{X}_{2}$

Persamaan ini menyatakan bahwa jika tidak ada kenaikan nilai dari variabel kepemimpinan visioner $\left(\mathrm{X}_{1}\right)$ dan iklim sekolah $\left(\mathrm{X}_{2}\right)$ maka efektivitas sekolah adalah 7,027. Koefisien regresi sebesar 0,273 dan 0,780 menyatakan bahwa setiap perubahan satu unit pada kepemimpinan visioner $\left(\mathrm{X}_{1}\right)$ dan iklim sekolah $\left(\mathrm{X}_{2}\right)$ maka akan memberikan kenaikan skor efektivitas sekolah sebesar 0,273 dan 0,780. Besarnya pengaruh atau korelasi $\left(\mathrm{r} \mathrm{x}_{1} \mathrm{x}_{2}\right)$ antara variabel kepemipinan visioner $\left(\mathrm{X}_{1}\right)$ dan iklim sekolah $\left(\mathrm{X}_{2}\right)$ terhadap efektivitas sekolah (Y) adalah 0,763 dengan $\alpha=0,05$. Apabila dikonsultasikan dengan kriteria penafsiran tentang indeks korelasi maka tergolong cukup kuat. Sedangkan besarnya sumbangan (kontribusi) variabel $\mathrm{X}_{1}$ dan variabel $\mathrm{X}_{2}$ secara bersama-sama terhadap $\mathrm{Y}$ (KP $\mathrm{x}_{1} \mathrm{x}_{2} \mathrm{Y}$ ) adalah 58,2

Untuk mengetahui derajat kebermaknaan (signifikansi) hubungan antara variabel $\mathrm{X}_{1}$ dan $\mathrm{X}_{2}$ secara bersama-sama terhadap $\mathrm{Y}$ bahwa sig $\left(0,000^{\mathrm{b}}\right)<0,05$, maka pengaruh kepemimpinan visioner dan iklim sekolah bersama-sama terhadap efektivitas sekolah tergolong signifikan (bermakna). Pengujian Hipotesis dilakukan dengan uji $\mathrm{F}$ diperoleh nilai $\mathrm{F}$ hitung 47,947 dengan taraf signifikansi $0,000<0,05$ sedangkan $\mathrm{F}$ tabel sebesar 0,673. Karena $\mathrm{F}$ hitung $(47,947)>\mathrm{F}$ tabel $(0,673)$ berarti persamaan regre si $\hat{Y}=7,027+$ $0,273 \mathrm{X}_{1}+0,780 \mathrm{X}_{2}$ signifikan, sehingga Ho ditolak dan $\mathrm{H} 1$ diterima, bahwa terdapat pengaruh positif dan signifikan dari kepemimpinan visioner dan iklim sekolah secara bersama-sama terhadap efektivitas sekolah di SMA Guligas IV kabupaten Indramayu.

Berdasarkan hasil perhitungan SPSS di atas, besarnya hubungan korelasi ganda antara variabel kepemimpinan visioner kepala sekolah $\left(\mathrm{X}_{1}\right)$ dan iklim sekolah $\left(\mathrm{X}_{2}\right)$ secara bersama-sama terhadap efektivitas sekolah (Y) adalah 0,763. Hal ini menunjukkan adanya pengaruh yang positif antara kepemimpinan visioner kepala sekolah $\left(\mathrm{X}_{1}\right)$ dan iklim sekolah $\left(\mathrm{X}_{2}\right)$ secara bersama-sama terhadap efektivitas sekolah (Y). Diperoleh data bahwa $\mathrm{R}$ square sebesar 0,562. Ini berarti bahwa koefisien determinasi $=r^{2} \times 100 \%=(0,582)^{2} \times 100 \%=$ 76,3\% artinya variabel Efektivitas sekolah (Y) dipengaruhi oleh variabel kepemimpinan kepala sekolah $(\mathrm{X} 1)$ dan variabel iklim sekolah $\left(\mathrm{X}_{2}\right)$ secara bersama-sama sebesar 76,3\%, 
dan sisanya sebesar 23,7\% dipengaruhi oleh variabel lain yang tidak diteliti dalam penelitian ini. Berdasarkan kategori interval korelasi diatas maka hubungan antara kepemimpinan visioner dengan efektivitas sekolah cukup kuat dan hubungan antara iklim sekolah dengan efektivitas sekolah rendah. Sedangkan bila kedua variabel ini diterapkan bersama-sama dapat memberikan korelasi cukup kuat

Berdasarkan temuan empirik yang menunjukkan adanya pengaruh yang signifikan terhadap implementasi kepemimpinan visioner dengan efektivitas sekolah, maka penelitian ini memberikan beberapa informasi bahwa: 1) implementasi kepemimpinan visioner pada SMA Guligas IV Kabupaten Indramayu memberikan pengaruh yang berarti terhadap efektivitas sekolah. 2) cara meningkatkan efektivitas sekolah di SMA Guligas IV Kabupaten Indramayu adalah dengan mengefektifkan implementasi kepemimpinan visioner, dan 3) persentase pengaruh implementasi kepemimpinan visioner terhadap efektivitas sekolah sebesar $33,9 \%$, sisanya dipengaruhi oleh variabel lain yang tidak diteliti dalam penelitian ini.

Berdasarkan temuan empirik yang menunjukkan adanya pengaruh yang signifikan terhadap implementasi iklim sekolah dengan efektivitas sekolah, maka penelitian ini memberikan beberapa informasi bahwa: 1) implementasi iklim sekolah pada SMA Guligas IV Kabupaten Indramayu memberikan pengaruh yang berarti terhadap efektivitas sekolah. 2) cara meningkatkan efektivitas sekolah di SMA Guligas IV Kabupaten Indramayu adalah dengan mengefektifkan implementasi iklim sekolah, dan 3) persentase pengaruh implementasi kepemimpinan visioner terhadap efektivitas sekolah sebesar 43,1\%, sisanya dipengaruhi oleh variabel lain yang tidak diteliti dalam penelitian ini.

Sedangkan berdasarkan temuan empirik yang menunjukkan adanya pengaruh yang signifikan terhadap implementasi kepemimpinan visioner kepala sekolah dan iklim sekolah dengan efektivitas sekolah, maka penelitian ini memberikan beberapa informasi bahwa: 1) implementasi kepemimpinan visioner kepala sekolah dan iklim sekolah pada SMA Guligas IV Kabupaten Indramayu memberikan pengaruh yang berarti terhadap efektivitas sekolah. 2) cara meningkatkan efektivitas sekolah di SMA Guligas IV Kabupaten Indramayu adalah dengan mengefektifkan implementasi kepemimpinan visioner kepala sekolah dan iklim sekolah, dan 3) persentase pengaruh implementasi kepemimpinan visioner terhadap efektivitas sekolah sebesar 58,2\%, sedangkan sisanya dipengaruhi oleh variabel lain yang tidak diteliti dalam penelitian ini. 


\section{PENUTUP}

Setelah melakukan penelitian dan pembahasan terhadap hasil penelitian ini maka dapat disimpulkan bahwa:

1. Terdapat pengaruh yang positif dan signifikan pada kepemimpinan visioner kepala sekolah terhadap terwujudnya efektivitas sekolah di SMA Se-Guligas IV Kabupaten Indramayu dengan besaran pengaruh $33,9 \%$.

2. Terdapat pengaruh yang positif dan signifikan pada iklim sekolah terhadap terwujudnya efektivitas sekolah di SMA Se-Guligas IV Kabupaten Indramayu dengan besaran pengaruh $43,1 \%$.

3. Terdapat pengaruh yang positif dan signifikan pada kepemimpinan visioner kepala sekolah dan iklim sekolah secara bersama-sama terhadap terwujudnya efektivitas sekolah di SMA Se-Guligas IV Kabupaten Indramayu dengan besaran 58,2\%.

Berdasarkan penelitian yang telah dilakukan dan hasil yang didapat maka penulis menyarankan kepada:

1. Pengambil kebijakan pendidikan baik dinas pendidikan, pengawas dan kepala sekolah di Kabupaten Indramayu agar dapat menumbuhkembangkan kepemimpinan visioner kepala sekolah dan iklim sekolah pada SMA yang menjadi binaannya mengingat ternyata kepemimpinan visioner dan iklim sekolah ini memberi pengaruh positif dan signifikan terhadap perwujudan efektivitas sekolah.

2. Pemerintah daerah provinsi Jawa Barat untuk dapat memperhatikan kebutuhan sekolah yang teridentifikasi antara lain melengkapi sarana fisik, memberikan kesempatan kepada guru untuk meningkatkan profesionalnya, meningkatkan peluang dan kesempatan kepada siswa untuk belajar di luar lingkungan sekolah, dimana indikator ini ternyata mempunyai pengaruh terhadap efektivitas sekolah.

3. SMA-SMA Guligas IV Kabupaten Indramayu yang menjadi objek penelitian supaya senantiasa meningkatkan efektivitas sekolahnya dengan cara terus mengembangkan manajemen sekolah kearah yang lebih baik lagi.

\section{UCAPAN TERIMAKASIH}

Pada kesempatan ini penulis ingin menyampaikan penghargaan dan terimakasih yang tulus kepada semua pihak yang telah membantu dalam pembuatan karya tulis ini. 


\section{DAFTAR PUSTAKA}

Kemdikbud. (2015). Laporan Hasil Ujian Nasional. http://118.98.234.50/lhun/grafik.aspx.

Kemdikbud. (2016). Data Sekolah. http://sekolah.data.kemdikbud.go.id/index.php/chome/.

Riduwan. (2007). Rumus dan Data Dalam Analisis Statistika cetakan ke-2. Bandung, Alfabeta

Rohiat. (2010). Manajemen Sekolah. Bandung: Refika Aditama.

Sergiovanni, T. J. (1987). The Principalship : a reflective practice perspective. Boston: Allyn and Bacon, Inc. 